\title{
REVIEW
}

\section{Gene therapy strategies for the treatment of pituitary tumours}

\section{G Castro}

Molecular Medicine Unit, Department of Medicine, University of Manchester, Stopford Building, Room 1·302, Oxford Road, Manchester M13 9PT, UK

\section{INTRODUCTION}

Gene therapy can be defined as the introduction of therapeutic nucleic acids into cells with the aim of ameliorating or curing a disease. Initially, gene therapy paradigms focused on single-gene disorders. Recently, it has become apparent that potential therapeutic nucleic acids can be considered as drugs and as such could also be used for treating a variety of diseases (Verma \& Somia 1997, Lowenstein 1997). With recent advances in gene transfer technology, gene therapy has become a reality, with more than 2100 patients currently undergoing clinical gene therapy trials (Marcel \& Grausz 1997). Given the high expectations from this new therapeutic modality and in spite of the lack of conclusive evidence for its efficacy from the initial trials, very valuable information has been gained from the preclinical and clinical trials.

There are two main methods for transferring therapeutic transgenes into affected tissues: transplantation of autologous cells genetically modified ex vivo and direct delivery of the therapeutic transgenes into the target tissue. As far as gene therapy methods are concerned, ex vivo methods are losing popularity in relation to in vivo approaches (59\% of patients by December 1994, and 39\% of patients by December 1995) (Marcel \& Grausz 1997).

Currently, there are two major approaches for transferring therapeutic genes into diseased cells: using viral and non-viral vectors. Viral vectors used for clinical gene therapy include retroviruses, herpes simplex type 1 viruses (HSV1), adenoassociated viruses (AAVs), lentiviruses and adenoviruses (Kozarsky \& Wilson 1993, Verma \& Somia 1997). Non-viral vectors include naked DNA, liposomes and DNA-protein complexes (Kay et al. 1997) (Table 1). The therapeutic potential of each approach needs to be evaluated individually, taking into account various factors, e.g. nature of the disease to be treated, desired duration of treatment, number and type of cells to be transduced, level of transgene expression required.

\section{RETROVIRAL VECTORS}

Retroviruses are a group of RNA viruses in which the genome is reverse-transcribed to doublestranded DNA in the infected cell. The genome comprises three genes named gag, pol and env, which encode viral structural proteins, reverse transcriptase and integrase, and the virion envelope protein respectively. The viral genome is flanked by long terminal repeats (LTRs) which mediate integration into the host genome and control expression of the viral genes, i.e. they act as promoter-enhancer sequences. The packaging sequence $(\Psi)$ mediates the packaging of the genomiclength RNA into virions and distinguishes viral RNA from cellular RNAs (Varmus et al. 1979, Bender et al. 1987, Brown et al. 1989).

Retroviral-based vectors currently used for gene delivery are replication-defective because of the deletion of the gag, pol and env genes. These functions are provided in trans using specially designed packaging cell lines, so that all that is needed to generate infectious virions are the LTRs and the packaging sequence ( $\Psi)$ (Miller 1992). Transcription of the gene of interest can be driven by the viral LTRs; alternatively, other promoter/ enhancer elements can be introduced together with the transgene. The recombinant retroviral vector is introduced into the appropriate packaging cell line, which produces all necessary viral proteins in trans, and therefore the culture medium contains the retroviral vectors. One of the main limitations of retroviral vectors is that they cannot infect non-dividing cells (Miller et al. 1990). They are 

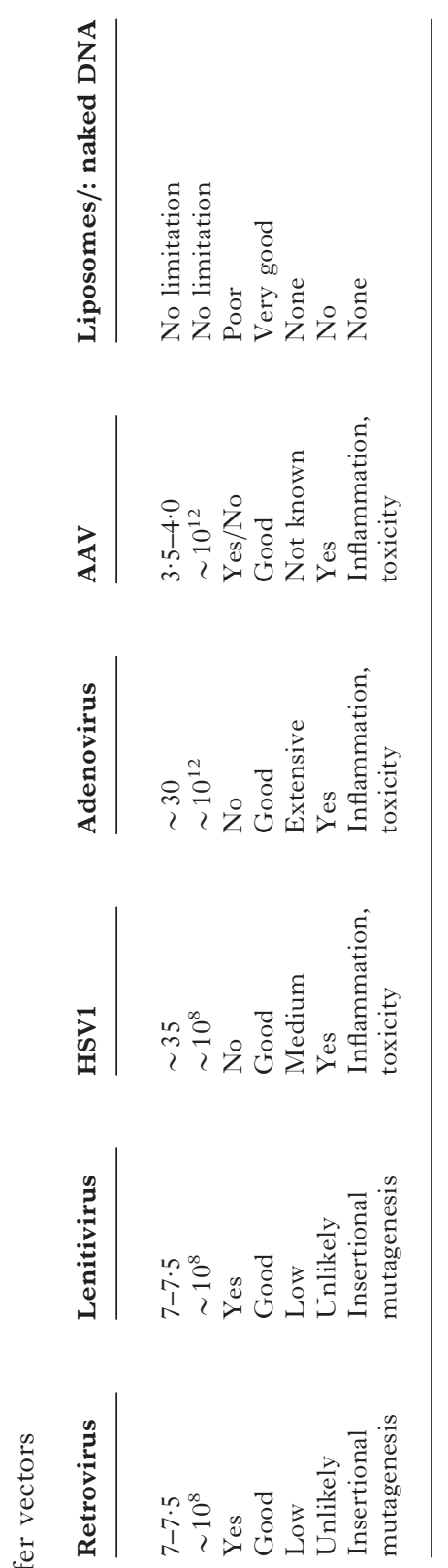

efficient at transducing cells in culture, but, taking into account that in vivo most cells are quiescent at any one time, this hampers the use of retrovirus vectors for in vivo gene transfer/therapy applications. Another disadvantage of retroviruses is that the virus titres that can be achieved are relatively low $\left(10^{7}-10^{8}\right.$ plaque-forming units $\left./ \mathrm{ml}\right)$. Also, the possibility of random integration of vector DNA into the host genome could lead to activation of oncogenes or disruption of tumour suppressor genes, although theoretically this possibility is almost negligible. To date, retroviruses based on the mouse Moloney leukaemia virus have been used most frequently in clinical trials (Marcel \& Grausz 1997).

More recently, a chimaeric Moloney-human lentiviral (human immunodeficiency virus (HIV)) vector has been generated which can transduce non-dividing cells such as neurons in the central nervous system of rodents (Naldini et al. 1996a). Like other retroviruses, HIV has the three gag, pol and $e n v$ genes, but it also carries genes that encode six accessory proteins, i.e. tat, rev, vpr, vpu, nef and vif.

Lentivirus vectors have been constructed with the transgene of interest inserted between the LTRs and packaging sequence (Naldini et al. 1996b). Some of the accessory genes can be excised without affecting vector production or infection efficiency (Naldini et al. 1996b). Infection in vivo in a variety of tissues like the brain, liver, muscle or pancreas has shown up to 6 months sustained expression (Blomet et al. 1997, Miyoshi et al. 1997). Unlike with classical retroviral vectors, 'shut off' of transgene expression has not been observed. There is little information available on possible immune reactions to lentiviral vectors, but no cellular immune response has been detected at the site of infection in the brain (Naldini et al. 1996b). These vectors can be produced at titres of $10^{9}$ virus particles $/ \mathrm{ml}$. A challenge with these vectors is to guarantee their safety for gene therapy applications in humans.

\section{ADENOVIRAL (AD) VECTORS}

Human adenoviruses cause mild upper respiratory tract infections, and the two most common serotypes (Ad2 and Ad5) are currently being developed as vectors for gene transfer and gene therapy. These adenoviruses are not oncogenic in humans, and live adenovirus vaccines have been effectively used in humans. Compared with other gene transfer systems available, adenovirus-based systems achieve the highest levels of gene expression per unit DNA. Furthermore, they are the only 
gene transfer system that can survive bloodstream delivery.

The basic characteristics of this virus have been extensively reviewed (Shenk 1996). The adenovirus genome is composed of linear double-stranded DNA approximately $36 \mathrm{kbp}$ long, divided into 100 map units (mu) of $360 \mathrm{bp}$ each. The viral genome contains short inverted terminal repeats (ITRs) at the $5^{\prime}$ and $3^{\prime}$ ends which are needed for viral DNA replication. Gene expression is divided into early (E1 through E4) and late (L1 through L5) regions, according to when expression takes place, i.e. before or after viral DNA replication. The adenoviral genome does not usually integrate into the host DNA; they are replicated as episomal elements within the nucleus of the target cell.

The replication-deficient recombinant adenovirus (RAd) vectors developed for gene transfer/gene therapy applications carry deletions of the entire $\mathrm{E} 1 \mathrm{a}$ and part of the E1b regions. In this way, space is made to insert therapeutic expression cassettes, and also, in the absence of the E1a gene product, the virus cannot replicate. Therefore no viral spread occurs after infection of target cells unless wild-type virus is present to complement the vectors.

Replication-defective adenoviruses are grown in cells that express the products of the $\mathrm{E} 1$ gene, i.e. stably transfected 293 cells, where very high viral titres can be obtained $\left(\sim 10^{11}-10^{12}\right.$ infectious adenovirus particles per $\mathrm{ml}$ ) (Lowenstein et al. 1996). Variations on the procedure for generating RAds have been described including additional deletions in the $\mathrm{E} 3$ and $\mathrm{E} 4$ regions and, more recently, deletions of all viral genes, 'gut-less' vectors, which contain only the elements that define the start and finish of the viral genome, and the viral packaging signal (Parks et al. 1996).

Several features make replication-deficient adenoviruses very attractive vectors for gene therapy applications, i.e. they can be easily generated and concentrated to high titres $\left(\sim 10^{12}\right.$ plaque-forming units $/ \mathrm{ml}$ ), they can transduce both dividing and non-dividing cells, they do not integrate into the host chromosomal DNA, and they are safe. These vectors have been used to infect a wide range of cells and tissues both in vitro and in vivo, eliciting high levels of transgene expression (Bajocchi et al. 1993, Freese et al. 1996, Geddes et al. 1996, 1997, Brown et al. 1997, Castro et al. 1997, Shering et al. 1997).

One of the main drawbacks of RAds for gene therapy applications is the limited duration of transgene expression after in vivo delivery. Transgene expression is extended in nude rats and mice or if the RAd is delivered together with immunosuppressants (Zsengeller et al. 1995, Geddes et al. 1996, Jooss et al. 1996, Hermens \& Verhaagen 1997,
Ilan et al. 1997). The immune reaction elicited by RAds can be evidenced by an early inflammatory response, which eliminates most of the initial viral load, and also a later cellular and humoural immune response (Wood et al. 1996). Therefore virally infected cells are eventually killed by cytotoxic lymphocytes, and the humoural immune response will generate specific antibodies to adenoviral proteins, preventing any subsequent readministration of the virus. In spite of these problems, adenoviruses are extremely useful vectors, if expression of therapeutic transgenes is needed for limited periods of time, i.e. for cancer gene therapy applications in which the aim is to kill the tumour cells in the shortest possible time, and inflammatory responses can be beneficial. One widely used approach is to deliver genes that can cause tumour cell killing or immune stimulating genes that will activate the immune response of the host specifically towards tumour cells. In these cases, the cellular immune response to RAd proteins should result in increased tumour cell death (Smith et al. 1997).

\section{AAV VECTORS}

AAVs are non-pathogenic single-stranded DNA viruses. The two genes, i.e. cap (capsid) and rep (replication), are flanked by ITRs which are located at the extreme ends of the AAV genome and contain the packaging sequence. The cap gene encodes the viral capsid proteins and the rep gene product is involved in viral replication and integration. AAVs need further genes to replicate which are provided by a helper virus such as adenovirus or HSV.

AAVs have recently been shown to transduce brain (McCown et al. 1996), liver (Snyder et al. 1997) and skeletal muscle (Xiao et al. 1996, Fisher et al. 1997). In the presence of the rep gene product, the viral DNA can integrate preferentially into human chromosome 19. The rep and cap genes are replaced with a transgene of interest to produce an AAV vector which normally has a cloning capacity of $3 \cdot 5-4 \cdot 0 \mathrm{~kb}$ of foreign DNA. Thus larger cDNAs or complex regulatory elements cannot be expressed using this vector. Preparation of AAV vectors is laborious, and up to $10^{11}-10^{12}$ viral particles $/ \mathrm{ml}$ can be obtained, but only one in 100 to 1000 particles will be infectious. To date there are no packaging cell lines available and therefore vector preparations have to be carefully purified of contaminating adenoviruses used as helpers. Also, the immunogenicity of AAVs needs to be investigated further, especially in view of the fact that $80 \%$ of the adult population has circulating antibodies to AAVs. 


\section{OTHER VIRAL VECTORS}

A number of other viral vectors are currently being developed. HSV1 can infect and establish long-term latent infections in neuronal cells. Therefore it is an attractive vector for performing gene therapy for neurological disorders. The HSV1 genome is large (150 kb encoding $\sim 80$ genes) and can be difficult to manipulate, but a rich source of mutants and genetic information is available. Around $10^{8}-10^{9}$ viral particles $/ \mathrm{ml}$ can be produced, but residual proteins are toxic to target cells (Lowenstein et al. 1994). Several genes can be deleted, allowing a larger cloning capacity. One of the main limitations of this vector system is the toxicity of recombinant HSV1 vectors for long-term gene expression to prolong neuronal cell survival in diseases such as Parkinson's; problems to be solved are how to avoid inducing an inflammatory response and how to deliver the virus to specific brain regions.

Vaccinia-virus-derived vectors are currently being used, mainly for generating vaccines (Moss 1996), i.e. for tumour treatment. The Sindbis and Semiliki Forest virus are being developed as cytoplasmic vectors which are not translocated into the nucleus (Berglund et al. 1993). A number of additional viral vectors based on Epstein-Barr virus, Simian virus 40, papilloma virus, non-human lentiviruses and hepatitis viruses are currently being developed by several groups. It is likely that chimaeric viruses will have the most desired properties for clinical gene therapy applications.

\section{NON-VIRAL DELIVERY SYSTEMS: LIPOSOMES AND NAKED DNA}

Naked plasmid DNA has been used as a gene delivery system both in vitro and in vivo. Direct infection of naked plasmid DNA into muscle has resulted in transfection levels similar to those obtained in vitro for fibroblasts (Wolff et al. 1990). Although plasmid DNA does not integrate into the host genome, expression of the transgene is long lived (Jiao et al. 1992, Davis et al. 1993). It has been hypothesised that uptake of DNA and long-term transgene expression within skeletal and cardiac muscle is due to the fact that the transverse tubules of the myofibres are in direct contact with the extracellular space and this makes DNA uptake very efficient (Acsadi et al. 1991). However, use of naked plasmid DNA for the treatment of genetic diseases of skeletal muscle would require efficient transfection and adequate levels of transgene expression within a large proportion of muscle tissue. Another possible application is the expression of transgenes in muscle for the development of vaccines (Fuller \& Haynes 1994, Lowrie et al. 1994, Webster et al. 1994).

Another approach to the delivery of genetic material within target cells is to encapsulate the plasmid DNA within a liposomal carrier. Two types of cationic lipids have been developed; the first has two alkyl chains in each cationic lipid molecule and the second uses cholesterol as the backbone. They both contain one or several amino groups which form complexes with the plasmid DNA through electrostatic interactions. In general, the transfection efficiency of these cationic lipids is improved when another lipid, e.g. dioleoylphosphatidylethanolamine, is incorporated (Felgner et al. 1994). In principle, cationic-lipid-based DNA delivery systems offer several advantages, i.e. they are less immunogenic, the DNA-lipid complexes are easy to prepare, there is no limit to the size of the transgenes that can be delivered, and they have less risk of generating tumorigenic mutations since plasmid DNA has very low integration frequency and cannot replicate. One disadvantage of this system is that it has much lower transgene expression potency and transduction efficiency when compared with viral delivery systems. This implies that the toxicity associated with cationiclipid-based delivery systems becomes an important issue to be considered. As with viral delivery systems, future developments should be aimed to achieve cell-type-specific transgene expression and delivery, tightly regulated levels of transgene expression and increased length of transgene expression.

\section{GENE THERAPY STRATEGIES FOR THE TREATMENT OF PITUITARY TUMOURS}

Pituitary tumours account for approximately $10-15 \%$ of all cranial tumours (Thapar et al. 1997). Although they are often considered as 'benign' adenomas, they produce distressing endocrine abnormalities, they can often exhibit suprasellar extensions into the cranium, and, depending on the size of the tumour, ophthalmoplegia and other neurological symptoms may be present. Owing to recent progress in endocrine assays, imaging techniques, transsphenoidal microsurgery, receptor-mediated pharmacology and radiotherapy, most pituitary tumours have become manageable disorders, with long-term survival or cure of the affected individuals. Nevertheless, for some of the most difficult tumours, such as certain large and locally invasive endocrine-active tumours, only partial success has been possible, and, in such cases, 
cure might prove impossible to achieve. The pathogenesis and molecular biology of pituitary adenomas, as well as the effectiveness of the currently used treatment strategies, have been extensively reviewed elsewhere (Molitch 1989, Wilson 1990, Bevan et al. 1992, Adams \& Burke 1993, Braba et al. 1993, Levy \& Lightman 1993, 1994, Shimon \& Melmed 1997). Therefore I will only outline possible gene therapy strategies that could be applicable for the treatment of pituitary tumours that prove resistant to conventional treatment strategies. Some of these strategies have been or are currently being developed for the treatment of other cancers, e.g. brain tumours, colon cancer, liver metastasis, breast cancer, both in animal models and in human clinical trials (Marcel \& Grausz 1997).

\section{Use of prodrug-activating genes}

The most commonly used prodrug-activating enzyme gene is the thymidine kinase $(t k)$ gene from HSV1 (Moolten 1986). HSV1-tk converts nucleoside analogues, e.g. acyclovir and ganciclovir, into their phosphorylated metabolites which then act as competitive inhibitors of endogenous nucleotides for incorporation into replicating DNA chains of proliferating cells, causing cell death. HSV1-tk can mediate ganciclovir tumour cell killing both in vitro and in vivo (Moolten 1994). The effectiveness of this approach can be enhanced by the 'bystander' effect in which non-transduced cells can be killed by the transfer of phosphorylated ganciclovir metabolites through gap junctions (Freeman et al. 1993, Vile \& Hart 1993). This strategy is currently being used for many gene therapy trials for brain tumours and also other peripheral cancers. Other commonly used genes that activate prodrugs include: the Escherichia coli cytosine deaminase $(c d)$ gene which activates 5-fluorocytosine to the cytotoxic agent 5 -fluorouracil, the E. coli guanine phosphoribosyltransferase $(g p t)$ gene which activates 6-thioxanthine and 6-thioguanine, the E. coli nitroreductase gene, the mammalian deoxycytidine kinase gene which activates cytosine arabinoside, the rat cytochrome P450 2B1 gene which activates cyclophosphamide/ ifosphamide, and the bacterial carboxypeptidase G2 gene which activates 4-(N,N-bis(2-iodoethyl) amino) phenoxycarbonyl L-glutamic acid (CMDA) (reviewed by Moolten 1994, Chiocca 1998).

A recombinant adenovirus vector expressing HSV1-tk under the control of a truncated major immediate early human cytomegalovirus promoter (MIEhCMV) has been recently generated and used to induce in vitro cell killing of anterior pituitary corticotrophic and prolactotrophic tumour cells, i.e. AtT20 and GH3 respectively (Dewey et al.
1997, Windeatt et al. 1998). These results suggest that these RAds could be used effectively to achieve gene therapy for pituitary tumours. Moreover, the $\mathrm{RAd} / \mathrm{tk}$ was found to be non-cytotoxic to the surrounding normal pituitary tissue, suggesting that this treatment would not affect the functioning of the normal anterior pituitary gland.

\section{Use of tumour suppressor genes and genes that regulate the cell cycle}

Tumour suppressor genes normally suppress cell proliferation. Both copies of the genes need to be mutated in order to initiate oncogenic transformation. The mutated or deleted p53 suppressor gene is associated with $50 \%$ of human cancers. However, to date, p53 mutations have not been detected in either secreting or non-secreting pituitary adenomas, carcinomas or their metastases (Levy et al. 1994, Shimon \& Melmed 1997). Therefore p53 probably plays no major role in pituitary tumorigenesis. A recent study demonstrated that deletions affecting chromosomes $11 \mathrm{q} 13$, 13q12-14 and 10q26 occur to a significantly greater extent in invasive than non-invasive pituitary tumours (Bates et al. 1997). 11q13 deletions have been reported in up to $30 \%$ of sporadic pituitary tumours (Bates et al. 1997). These observations suggest that tumour suppressor gene interaction is involved in tumour progression and, once identified, they could become possible targets for gene therapy strategies. Pituitary adenomas can also develop as part of multiple endocrine neoplasia type 1 (MEN1). The gene responsible for MEN1 has recently been cloned (Chandrasekharappa et al. 1997). Mutations and allelic deletions at the precise location of the MEN1 genes were investigated in sporadic pituitary adenomas; the results did not show any mutations or deletions of the MEN1 gene in the majority of these tumours (Zhuang et al. 1997). Thus this tumour suppressor gene is probably not a possible target for gene therapy in non-MEN1 tumours (i.e. the vast majority).

The retinoblastoma $(\mathrm{Rb})$ gene product regulates the cell cycle and plays an important role in regulating cell differentiation. It has recently been demonstrated that heterologous disruption of the $\mathrm{Rb}$ gene in mice leads to $100 \%$ incidence of pro-opiomelanocortin-expressing pituitary tumours which originate from the intermediate lobe of the pituitary gland ( $\mathrm{Hu}$ et al. 1994). Similarly, mice with mutations in the $\mathrm{p} 27^{\mathrm{kip} 1}$ gene, often develop pituitary tumours (Nakayama et al. 1996). In humans, it has been suggested that another tumour suppressor gene located in chromosome $13 \mathrm{q}$ adjacent to the $\mathrm{Rb}$ locus, and not the $\mathrm{Rb}$ gene itself, 
may play a role in the development of invasive pituitary adenomas and carcinomas (Shimon \& Melmed 1997). Recently a gene therapy strategy has been successfully used in vivo for the treatment of intermediate lobe pituitary tumours (Riley et al. 1996). Adenoviruses encoding the $\mathrm{Rb} \mathrm{cDNA}$ have been used to treat spontaneous pituitary melanotroph tumours arising in immunocompetent $\mathrm{Rb}+$ / - mice. Intratumour delivery of $\mathrm{RAd} / \mathrm{Rb}$ decreased tumour cell proliferation, re-established innervation by dopaminergic neurons which regulate cell growth, inhibited tumour growth, and prolonged the life spans of treated animals. This study therefore provides good proof of the amenability of this gene therapy strategy for the treatment of pituitary tumours, although it would need to be adapted by using other tumour suppressor genes useful for human therapeutic applications.

\section{Growth factors and their receptors involved in modulating angiogenesis}

The process of angiogensis occurs in many physiological conditions, but it also plays a major role in the sustained growth of solid tumours. It has also been shown that angiogenesis is essential for the growth of oestrogen-induced prolactin-secreting anterior pituitary tumours (Elias \& Weiner 1984). It was recently demonstrated that fumagillin and its analogue TNP-470, which are known to selectively inhibit endothelial cell proliferation, inhibited prolactin production and prolactotrophic cell density and proliferation and suppressed neovascularisation in Fischer 374 rats bearing prolactinomas induced by oestrogen treatment (Takachi et al. 1994, Stepien et al. 1996). These results provide strong evidence for the anti-prolactinoma effects of inhibitors of angiogenesis in this pituitary prolactinoma model. Therefore the process of neovascularisation of expanding pituitary adenomas offers a target for experimental gene therapy approaches based on inhibiting angiogenesis. Several growth factors and their respective receptors are known to be involved in the process of angiogenesis and have been shown to be necessary for tumour growth. These include vascular endothelial growth factor (VEGF) (Samoto et al. 1995) and its receptor (VEGFR-1 or flt-1 and VEGFR-2 or flk-1) (Milauer et al. 1994), transforming growth factor $\alpha$ $(\mathrm{TGF} \alpha)$ and its receptor, epidermal growth factor (EGF) and its receptor, TGF $\beta$, human platelet factor 4 (PF4) and its receptor (Maione et al. 1991) and basic fibroblast growth factor (bFGF) and its receptor (Nabel et al. 1993).

Concerning pituitary tumorigenesis, it has been shown that EGF and its receptor (EGFR) are present in human pituitary adenomas, and the levels of EGFR correlate with tumour aggressiveness (LeRiche et al. 1996). High molecular mass forms of bFGF have also been identified and characterised in human pituitary adenomas ( $\mathrm{Li}$ et al. 1992). Normal human pituitary tissue and secreting and nonsecreting adenomas can also express TGF $\alpha$ (Driman et al. 1992, Ezzat et al. 1995). Moreover, a lactrotroph-targeted $\mathrm{TGF} \alpha$-overexpressing transgenic mouse exhibited hyperplasia of prolactotrophic cells and developed prolactinomas (McAndrew et al. 1995). Gene therapy strategies involving anti-angiogenic genes may provide an effective in vivo therapy, i.e. expression of antisense cDNAs for bFGF, EGF or VEGF, or the expression of dominant negative mutants of their respective receptors. These strategies have been successfully used in vivo for treatment of brain tumours in animal models (Milaeur et al. 1994, Redekop \& Naus 1995, Saleh et al. 1996).

\section{OTHER GROWTH FACTORS}

Nerve growth factor (NGF) is a neurotrophic protein that promotes the growth, differentiation and survival of neurons of the peripheral sympathetic nervous system, the ascending cholinergic neurons of the basal forebrain and sensory nerve cells derived from the neural crest (Levi-Montalcini 1987, Higgins et al. 1989). It has also been reported that endocrine cells are responsive to NGF (Missale et al. 1991). In a recent study, the same group reported that human prolactinomas that were totally resistant to pharmacological therapy because they lacked D-2 receptors for dopamine expressed NGF receptors (Missale et al. 1993). They also demonstrated that, after exposure to NGF, tumour cells decreased their proliferation rate, lost their capacity to form colonies in soft agar, lost their tumorigenic capacity in nude mice and re-expressed the D-2 receptor. These results indicate that short-term treatment with NGF may induce the reversion of human prolactinomas to a more differentiated less malignant dopamine-sensitive prolactotroph-like state (Missale et al. 1993). This study raises the possibility that a short-term gene therapy strategy, based on the delivery of NGF to the tumour in situ, may restore the susceptibility of refractory tumours to conventional treatment with D-2 agonists.

\section{CONCLUSION}

The events that mediate viral entry into cells and the expression of transgenes encoded within the 
viral genome have been the subject of intensive research during the last decade. This, coupled with the interest in developing techniques that allow gene transfer and expression within mammalian cells and tissues, has led to the development and use of modified viruses as vectors. Efficient transgene expression within all cell types of the anterior pituitary gland with no apparent cytotoxicity has recently been achieved using RAd vectors (Castro et al. 1997). These RAds have also been successfully used for gene transfer into mouse (Riley et al. 1996), rat (Castro et al. 1997) and human pituitary tumour cells (Freese et al. 1996) both in vitro and in vivo. It is also possible to engineer cell-type-specific and regulatable expression cassettes within recombinant adenovirus vectors for the expression of therapeutic genes within a specific cell population of the anterior pituitary gland which can also be turned 'on' and 'off' as required using the tetracyclineinducible system (Gossen et al. 1994, Massie et al. 1998). Furthermore, it is now feasible to engineer adenoviral vectors with a determined tropism and to produce them at high titres and purity. This, in combination with carefully designed and controlled clinical trials, should enable the assessment of whether virus-mediated gene therapy could become a useful strategy for the treatment of currently difficult-to-treat pituitary tumours.

\section{ACKNOWLEDGEMENTS}

I would like to acknowledge The Cancer Research Campaign (UK), The Royal Society and The Wellcome Trust for supporting the work on gene transfer into the anterior pituitary gland in vitro and in vivo and the use of suicide gene therapy for tumour treatment. I would also like to thank The British Heart Foundation, the MRC (UK), the BBSRC, REMEDI, The Sir Halley Stewart Trust and The Parkinson's Disease Society for supporting several gene therapy projects in my laboratory. I am grateful to Mrs Ros Poulton for careful and enthusiastic secretarial assistance and to Professor P R Lowenstein for his encouragement and useful discussions and comments.

\section{REFERENCES}

Acsadi G, Dickson G, Love DR, Jani A, Walsh FS, Gurunsinghe A, Wolff JA \& Davies KE 1991 Human dystrophin expression in mdx mice after intramuscular injection of DNA constructs. Nature 352 815-818.

Adams CBT \& Burke CW 1993 Current modes of treatment of pituitary tumours. British Fournal of Neurosurgery 7 123-128.
Bajocchi G, Feldman SH, Crystal RG \& Mastrangeli A 1993 Direct in vivo gene transfer into ependymal cells in the central nervous system using recombinant adenovirus vectors. Nature Genetics 3 229-234.

Bates AS, Farrell WE, Bicknell EJ, McNicol AM, Talbot AJ, Broome JC, Perrett CW, Thaker RV \& Clayton RN 1997 Allelic deletion in pituitary adenomas reflects aggressive biological activity and has potential value as a prognostic marker. Fournal of Clinical Endocrinology and Metabolism 82 818-824.

Bender MA, Palmer TD, Gelinas RE \& Miller AD 1987 Evidence that the packaging signal of moloney murine leukemia virus extends into the gag region. Fournal of Virology 61 1639-1646.

Berglund P, Sjoberg M, Garoff H, Atkins GJ, Sheahan BJ \& Liljestrom P 1993 Semliki Forest virus expression system: production of conditionally infectious recombinant particles. Biotechnology 11 916-920.

Bevan JS, Webster J, Burke CW \& Scanlon MF 1992 Dopamine agonists and pituitary tumour shrinkage. Endocrine Reviezus 13 220-240.

Blomet U, Naldini L, Kafri T, Trono D, Verma IM \& Gage FH 1997 Highly efficient and sustained gene transfer in adult neurons with a lentivirus vector. Fournal of Virology 71 6641-6649.

Braba M, Rajan B, Traish D \& Ashley S 1993 The long-term efficacy of conservative surgery and radiotherapy in the control of pituitary adenomas. Clinical Endocrinology $\mathbf{3 8}$ 571-578.

Brown OA, Santer RM, Shering AF, Larregina AT, Morelli AE, Southgate TD, Castro MG \& Lowenstein PR 1997 Gene transfer into enteric neurons of the rat small intestine in organ culture using a replication defective recombinant herpes simplex virus type 1 (HSV1) vector, but not recombinant adenovirus vectors. Gene Therapy 4 331-338.

Brown PO, Bowerman B, Varmus HE \& Bishop JM 1989 Retroviral integration: structure of the initial covalent product and its precursor, and a role for the viral IN protein. Proceedings of the National Academy of Sciences of the USA 86 2525-2529.

Castro MG, Goya RG, Sosa YE, Rowe J, Larregina A, Morelli A \& Lowenstein PR 1997 Expression of transgenes in normal and neoplastic anterior pituitary cells using recombinant adenoviruses: long term expression cell cycle dependency, and effects on hormone secretion. Endocrinology 138 2184-2194.

Chandrasekharappa SC, Guru SC, Manickam P, Olufemi SE, Collins FS, Emmert-Buck MR, Debelenko LV, Zhuang Z, Lubensky IA, Liotta LA, Crabtree JS, Wang Y, Roe BA, Weisemann J, Boguski MS, Agarwal SK, Kester MB, Kim YS, Heppner C, Dong Q, Spiegel AM, Burns AL \& Marx SJ 1997 Positional cloning of the gene for multiple endocrine neoplasia-type 1. Science 276 404-407.

Chiocca EA 1998 Experimental and clinical gene therapies for brain tumors: In Gene Therapy for Neurological Disorders and Brain Tumours, ch 11, pp 191-203. Eds EA Chiocca \& XO Breakefield. Totowa, NJ: Humana Press.

Davis HL, Whalen RG, Demeneix BA 1993 Direct gene transfer into skeletal muscle in vivo: factors affecting efficiency of transfer and stability of expression. Human Gene Therapy 4 151-159.

Dewey RA, Rowe J, Forrest Z, Morelli A, Klatzmann D, Wilkinson G, Lowenstein PR \& Castro MG 1997 Adenovirus vectors for gene therapy of brain tumours. Abstracts of the Society for Neuroscience, part 2, 2447, no. 951.5 .

Driman DK, Korbin MS, Kudlow JE \& Asa SL 1992 Transforming growth factor- $\alpha$ in normal and neoplastic 
human endocrine tissue. Human Pathology 23 $1360-1365$.

Elias KA \& Weiner RI 1984 Direct arterial vascularization of estrogen-induced prolactin secreting anterior pituitary tumors. Proceedings of the National Academy of Sciences of the USA 81 4549-4554.

Ezzat S, Walpola IA, Ramyar L, Smyth HS \& Asa SKL 1995 Membrane anchored expression of transforming growth factor- $\alpha$ in human pituitary adenoma cells. Fournal of Clinical Endocrinology and Metabolism 80 534-539.

Felgner JH, Kumar R, Sridhar CN, Wheeler CJ, Tsai YJ, Border R, Ramsey P, Martin M \& Felgner PL 1994 Enhanced gene delivery and mechanism studies with a novel series of cational lipid formulations. Fournal of Biological Chemistry 269 2550-2561.

Fisher KJ, Jooss K, Alston J, Yang Y, Haecker SE, High K, Pathak R, Raper SE \& Wilson JM 1997 Recombinant adeno-associated virus for muscle directed gene therapy. Nature Medicine 3 306-312.

Freeman SM, Abboud CN, Whartenby KA, Packman CH, Koeplin DS, Moolten FL \& Abraham GN 1993 The 'bystander effect': tumor regression when a fraction of the tumor mass is genetically modified. Cancer Research $\mathbf{5 3}$ 5274-5283

Freese A, During MJ, Davidson BL, Gennarelli TA, Kaplitt MG, Flamm ES \& Snyder RJ 1996 Transfection of human lactotroph adenoma cells with an adenovirus vector expressing tyrosine hydroxylase decreases prolactin release. Fournal of Clinical Endocrinology and Metabolism $\mathbf{8 1}$ 2401-2404.

Fuller DH \& Haynes JR 1994 A qualitative progression in HIV type 1 glycoprotein 120 -specific cytotoxic cellular and humoral immune responses in mice receiving a DNA-based glycoprotein 120 vaccine. AIDS Research and Human Retroviruses 10 1433-1441.

Geddes BJ, Harding TC, Hughes DS, Byrnes AP, Lightman SL, Conde G \& Uney JB 1996 Persistent transgene expression in the hypothalamus following stereotaxic delivery of a recombinant adenovirus: suppression of the immune response with cyclosporin. Endocrinology 137 $5166-5169$.

Geddes BJ, Harding TC, Lightman SL \& Uney JB 1997 Long-term gene therapy in the CNS: reversal of hypothalamic diabetes insipidus in the Brattleboro rat by using an adenovirus expressing arginine vasopressin. Nature Medicine 3 1402-1404.

Gossen MA, Bonin AL, Freundlieb S \& Bujard H 1994 Inducible gene expression systems for higher eukaryotic cells. Current Opinion in Biotechnology 5 516-520.

Hermens WT \& Verhaagen J 1997 Adenoviral vector-mediated gene expression in the nervous system of immunocompetent Wistar and T cell-deficient nude rats: preferential survival of transduced astrogial cells in nude rats. Human Gene Therapy 8 1049-1063.

Higgins GA, Koh S, Chen KS \& Gage FH 1989 NGF receptor gene expression and cholinergic neuronal hypertrophy within the basal forebrain of the adult rat. Neuron 3 247-256.

Hu N, Gutsmann A, Herbert DC, Bradley A, Lee WH \& Lee EY-HP 1994 Heterozygous $R b_{-}{ }^{1 \Delta 20} /+$ mice are predisposed to tumors of the pituitary gland with a nearly complete penetrance. Oncogene 9 1021-1027.

Ilan Y, Jona VK, Sengupta K, Davidson A, Horwitz MS, Chowdbury NR \& Chowdhury JR 1997 Transient immunosuppression with FK506 permits long term expression of therapeutic genes introduced into the liver using recombinant adenvoiruses in the rat. Hepatology 26 949-956.
Jiao S, Williams P, Berg RK, Hodgeman BA, Liu L, Repetto G \& Wolff JA 1992 Direct gene transfer into nonhuman primate myofibers in vivo. Human Gene Therapy 3 21-33.

Jooss K, Ertl HCJ \& Wilson JM 1996 Cyclophosphamide diminishes inflammation and prolongs transgene expression following delivery of adenoviral vectors to mouse liver and lung. Human Gene Therapy 7 1555-1566.

Kay MA, Liu D \& Hoogerbrugges PM 1997 Gene therapy. Proceedings of the National Academy of Sciences of the USA 94 12744-12746.

Kozarsky KF \& Wilson JM 1993 Gene therapy: adenovirus vectors. Current Opinion in Genetics and Development 3 499-503.

LeRiche VK, Asa SL \& Ezzat S 1996 Epidermal growth factor and its receptor (EGF-R) correlates with tumour aggressiveness. Fournal of Clinical Endocrinology.and Metabolism 81 656-662.

Levy A \& Lightman SL 1993 The pathogenesis of pituitary adenomas. Clinical Endocrinology 38 559-570.

Levy A \& Lightman SL 1994 Diagnosis and management of pituitary tumours. British Medical Fournal 308 1087-1091.

Levy A, Hall L, Yeudall WA \& Lightman S 1994 p53 gene mutations in pituitary adenomas: rare events. Clinical Endocrinology 41 809-814.

Levi-Montalcini R 1987 The nerve growth factor 35 years later. Science 237 1154-1162.

Li Y, Koga M, Kasayam S, Matsumoto K, Arita N, Hayakawa T \& Sato B 1992 Identification and characterization of high molecular weight forms of basic fibroblast growth factor in human pituitary adenomas. Fournal of Clinical Endocrinology and Metabolism 75 1436-1441.

Lowenstein PR 1997 Why are we doing so much cancer gene therapy? Disentangling the scientific basis from the origins of gene therapy. Gene Therapy 4 755-756.

Lowenstein PR, Morrison E, McKee T, Stow ND, Preston CM, Clissold, P \& Castro MG 1994 Use of recombinant vectors derived from herpes simplex virus 1 mutant $t s \mathrm{~K}$ for short term expression of genes encoding cytoplasmic and membrane anchored proteins in postmitotic neurones and glial cells in vitro. Neuroscience 60 1059-1077.

Lowenstein PR, Shering AF, Bain D, Castro MG \& Wilkinson GWG 1996 The use of adenovirus vectors to transfer genes to identified target brain cells in vitro. In Protocols for Gene Transfer in Neuroscience: Towards Gene Therapy of Neurological Disorders, ch 8, pp 93-114. Eds PR Lowenstein \& LW Enquist. London: John Wiley \& Sons.

Lowrie DB, Tascon RE, Colston MJ \& Silva CL 1994 Towards a DNA vaccine against tuberculosis. Vaccine 12 $1537-1540$.

McAndrew J, Paterson AJ, Asa SL, McCarthy KJ \& Kudlow JE 1995 Targeting of transforming growth factor- $\alpha$ expression to pituitary lactotrophs in transgenic mice results in selective lactotroph proliferation and adenomas. Endocrinology 136 4479-4488.

McCown TJ, Xiao X, Li J, Bresse GR \& Samulski RJ 1996 Differential and persistent expression patterns of CNS gene transfer by an adeno-associated virus (AAV) vector. Brain Research 713 99-107.

Maione TE, Gray GS, Hunt AJ \& Sharpe RJ 1991 Inhibition to tumor growth in mice by an analogue of platelet factor 4 that lacks affinity for heparin and retains potent angiostatic activity. Cancer Research 51 2077-2083.

Marcel T \& Grausz JD 1997 The TMC worldwide gene therapy enrolment report, end 1996. Human Gene Therapy 8 $775-800$.

Massie B, Couture F, Lamoureaux L, Mosser DD, Guilbault C, Joliceour P, Belanger F \& Yves Langelier 1998 Inducible overexpression of a toxic protein by an adenovirus vector 
with a tetracycline-regulatable expression cassette. Fournal of Virology 72 2289-2296.

Milauer B, Shawyer LK, Plate KH, Risau W \& Ullrich A 1994 Glioblastoma growth inhibited in vivo by a dominantnegative Flk-1 mutant. Nature 367 576-578.

Miller AD 1992 Retroviral vectors. Current Topics in Microbiology and Immunology 158 1-24.

Miller DG, Adam MA \& Miller AD 1990 Gene transfer by retrovirus vectors occurs only in cells that are actively replicating at the time of infection. Molecular and Cellular Biology 10 1239-1242.

Missale C, Castelletti L, Boroni F, Memo M \& Spano PF 1991 Epidermal growth factor induces the functional expression of dopamine receptors in the GH3 cell line. Endocrinology 128 13-20.

Missale C, Boroni F, Losa M, Giovanelli M, Zanellato A, Dal Toso R, Balsari A \& Spano PR 1993 Nerve growth factor suppresses the transforming phenotype of human prolactinomas. Proceedings of the National Academy of Sciences of the USA $907961-7965$.

Miyoshi H, Takahashi M, Gage FH \& Verma IM 1997 Stable and efficient gene transfer into the retina using an HIVbased lentiviral vector. Proceedings of the National Academy of Sciences of the USA 94 10319-10323.

Molitch ME 1989 Management of prolactinomas. Annual Review of Medicine 40 225-232.

Moolten FL 1986 Tumor chemosensitivity conferred by inserted herpes thymidine kinase genes: paradigm for a prospective cancer control strategy. Cancer Research 46 5276-5281.

Moolten FL 1994 Drug sensitivity ('suicide') genes for selective cancer chemotherapy. Cancer Gene Therapy 1 279-287.

Moss B 1996 Genetically engineered poxviruses for recombinant gene expression, vaccination, and safety. Proceedings of the National Academy of Sciences of the USA 93 11341-11348.

Nabel EG, Yang Z, Plautz G, Forough R, Zhan Y, Haudenschild CC, Maciag T \& Nabel GJ 1993 Recombinant fibroblast growth factor-1 promotes intimal hyperplasia and angiogenesis in arteries in vivo. Nature 362 844-846.

Nakayama K, Ishida N \& Shirane M 1996 Mice lacking $\mathrm{p} 27^{\mathrm{Kip} 1}$ display increased body size, multiple organ hyperplasia, retinal dysplasia, and pituitary tumours. Cell $\mathbf{8 5}$ 707-720.

Naldini L, Blomer U, Gage FH, Trono D \& Verma I $1996 a$ Efficient transfer, integration, and sustained long-term expression of the transgene in adult rat brains injected with a lentiviral vector. Proceedings of the National Academy of Sciences of the USA 93 11382-11389.

Naldini L, Blomer U, Gallay P, Ory D, Mulligan R, Gage FH, Verma IM \& Trono D $1996 b$ In vivo gene delivery and stable transduction of non dividing cells by a lentiviral vector. Science 272 263-267.

Parks RJ, Chen L, Anton M, Sankar U, Rudnicki MA \& Graham FL 1996 A helper dependent adenovirus vector system: removal of helper virus by Cre-mediated excision of the viral packaging signal. Proceedings of the National Academy of Sciences of the USA 93 13565-13570.

Redekop GJ \& Naus CCG 1995 Transfection with bFGF sense and antisense cDNA resulting in modification of malignant glioma growth. Fournal of Neurosurgery 82 83-90.

Riley DJ, Nikitin AY \& Lee WH 1996 Adenovirus-mediated retinoblastoma gene therapy suppresses spontaneous pituitary melanotroph tumours in $\mathrm{Rb}^{+/-}$mice. Nature Medicine 2 1316-1321.

Saleh M, Stacker SA \& Wilks AF 1996 Inhibition of growth of C6 glioma cells in vivo by expression of antisense vascular endothelial growth factor sequence. Cancer Research $\mathbf{5 6}$ 393-401.

Samoto K, Ikezaki K, Ono M, Shono T, Kohno K, Kuwano M \& Fukui M 1995 Expression of vascular endothelial growth factor and its possible relation with neovascularization in human brain tumors. Cancer Research 55 1189-1193.

Shenk T 1996 Adenoviridae: the viruses and their replication. In Field Virology, edn 3, ch 30, pp 979-1016, Eds BN Fields, DM Knipe, PM Howley et al. Philadelphia: Lippincott-Raven.

Shering AF, Bain D, Stewart K, Epstein AL, Castro MG, Wilkinson GWG \& Lowenstein PR 1997 Cell-type specific expression in brain cell cultures from the short human cytomegalovirus major immediate early promoter depends on whether it is inserted into herpesvirus or adenovirus vectors. Fournal of General Virology 78 445-459.

Shimon I \& Melmed S 1997 Genetic basis of endocrine disease. Pituitary tumour pathogenesis. Fournal of Clinical Endocrinology and Metabolism 82 1675-1681.

Smith JG, Raper SE, Wheeldon EB, Hackney D, Judy K, Wilson JM \& Ect SL 1997 Intracranial administration of adenovirus expressing HSV-TK in combination with ganciclovir produces a dose-dependent, self-limiting inflammatory response. Human Gene Therapy 8 943-954.

Snyder RO, Miao CH, Patijin GA, Spratt SK, Danos O, Nagy D, Gown AM, Winther B, Meuse L, Cohen LK, Thompson AR \& Kay MA 1997 Persistent and therapeutic concentrations of human factor IX in mice after hepatic gene transfer of recombinant AAV vectors. Nature Genetics 16 270-276.

Stepien H, Grochal M, Zielinski KW, Mucha S, Kunert-Radek J, Kulig A, Stawowy A \& Pisarek H 1996 Inhibitory effects of fumagillin and its analogue TNP-470 on the function, morphology and angiogenesis of an oestrogen-induced prolactinoma. Fournal of Endocrinology 150 99-106.

Takachi A, Uozumi T, Kawamoto K, Ito A, Kurisu K \& Sudo K 1994 Inhibitory effect of TNP-470, a new antiangiogenic agent, on the estrogen induced rat pituitary tumors. Anticancer Research 14 157-162.

Thapar K, Kovacs K \& Laws ER 1997 Pituitary tumours. In Cancer of the Nervous System, ch 19, pp 363-403. Eds PMcL Black and JS Loeffler. Oxford: Blackwell Science.

Varmus HE, Shank PR, Hughs SE, King H-J, Heasley S, Majors J, Vogt PK \& Bishop JM 1979 Synthesis, structure, and integration of the DNA of RNA tumor viruses. Cold Spring Harbour Symposium. Quantitative Biology 43 851-864.

Verma IM \& Somia N 1997 Gene therapy: promises, problems and prospects. Nature $389239-242$.

Vile RG \& Hart IR 1993 Use of tissue-specific expression of the herpes simplex virus thymidine kinase gene to inhibit growth of established murine melanomas following direct intratumoral injection of DNA. Cancer Research $\mathbf{5 3}$ 3860-3864.

Webster RG, Fynan EF, Santoro JC \& Robinson H 1994 Protection of ferrets against influenza challenge with a DNA vaccine to the hemagglutinin. Vaccine 12 1495-1498.

Wilson CB 1990 Role of surgery in the management of pituitary tumours. Neurosurgery Clinics of North America 1 139-159.

Windeatt S, Dewey RA, Perone MJ, Gonzalez-Nicolini V, Larregina A, Morris I, Lowenstein PR \& Castro MG 1998 Use of herpes simplex type 1 thymidine kinase (HSV1-TK) for gene therapy treatment of pituitary adenomas. Abstracts of the Society for Neuroscience, part 2, 2165, no. 859.6.

Wolff JA, Malone RW, Williams P, Chong W, Acsadi G, Jani A \& Felgner PL 1990 Direct gene transfer into mouse muscle in vivo. Science 247 1465-1468. 
Wood MJA, Charlton HM, Wood KJ, Kajiwara K \& Byrnes AP 1996 Immune-responses to adenovirus vectors in the nervous system. Trends in Neurosciences 19 497-501.

Xiao X, Li J \& Samulski RJ 1996 Efficient long-term gene transfer into muscle tissue of immunocompetent mice by adeno-associated virus vector. Fournal of Virology $\mathbf{7 0}$ 8098-8108.

Zhuang Z, Ezzat SZ, Vortmeyer AO, Weil R, Oldfield EH, Park WS, Pack S, Huang S, Agarwal SK, Guru SC, Manickam P, Debelenko LV, Kester MB, Olufemi SE,
Heppner C, Crabtree JS \& Burns L 1997 Mutations of the MEN1 tumour suppressor gene in pituitary tumours. Cancer Research 57 5446-5451.

Zsengeller ZK, Wert SE, Hull WM, Hu X, Yei S, Trapnell BC \& Whitsett JA 1995 Persistence of replication-deficient adenovirus-mediated gene transfer in lungs of immunedeficient (nu/nu) mice. Human Gene Therapy 6 $457-467$.

REVISED MANUSCRIPT RECEIVED 7 August 1998 